\title{
Analisis Serat Pelepah Batang Pisang Kepok Material Fiber Komposit Matriks Recycled Polypropylene (RPP) Terhadap Sifat Mekanik dan SEM
}

\author{
Tumpal Ojahan R.,Tri Cahyono ${ }^{1}$ \\ ${ }^{1}$ Program Studi Teknik Mesin, Fakultas Teknik Universitas Malahayati \\ Jl.Pramuka No. 27 Kemiling, Bandar Lampung, Email : tumpal_ojahan @yahoo.com
}

\begin{abstract}
Abstrak
Material logam pada berbagai komponen produk semakin berkurang, oleh karena itu banyak dikembangkan material komposit yang mempunyai sifat yang sesuai dengan karakteristik material logam. Salah satu material yang banyak dikembangkan saat ini adalah komposit. Komposit yang digunakan pada penelitian ini dari serat pelepah batang pisang kepok dengan fraksi volume 8\%, 12\%, 38\%, 42\% dengan Matriks Recycled Polypropylene. Penelitian ini bertujuan untuk mengetahui kekuatan tarik, kekuatan bending, kekuatan impact yang optimal serta untuk mengetahui jenis patahan dengan pengamatan Scanning Electron Microscope (SEM). Dari hasil uji tarik tegangan-regangan terdapat kekuatan tarik yang optimal pada fraksi volume Filler 38\% : Matriks 62\%, dengan tegangan tarik $59,3200 \mathrm{~N} / \mathrm{mm}^{2}$. Pengujian bending fraksi volume yang paling optimal terdapat pada fraksi volume $38 \%$ Filler :62\% Matriks. Dengan tegangan lentur 86,3001 N/mm². Pengujian impact fraksi volume yang paling optimal pada fraksi volume $42 \%$ Filler: 58\% Matriks, dengan energi impact 1,821 J. Pada pengamatan SEM terlihat bahwa fraksi volume 38\% Filler : 62\% Matriks paling optimal karena dengan adanya ikatan Matriks dan serat menyatu dengan sempurna. Penelitian ini dapat disimpulkan bahwa pengaruh fraksi volume serat batang pisang sebagai penguat (filler) dan recycled polypropylene (RPP) sebagai pengikat (Matriks) pada material komposit akan mempengaruhi kekuatan material komposit ini lebih kuat dan lebih baik dengan perbandingan Filler 38\% : Matriks 62\%. Apabila digunakan perbandingan fraksi volume diatas $38 \%$ filler, sifat mekaniknya sudah mengalami penurunan Kata Kunci : komposit, serat, recycled polypropylene (rpp), uji tarik, uji bending, uji impact, SEM.
\end{abstract}

\section{PENDAHULUAN}

Perkembangan dunia industri sekarang ini menyebabkan kebutuhan material makin meningkat terutama untuk sebuah produk. Penggunaan material logam pada berbagai komponen produk semakin berkurang. Hal ini diakibatkan oleh beratnya komponen yang terbuat dari logam, proses pembentukannya yang relatif sulit, dapat mengalami korosi dan biaya produksinya mahal, oleh karena itu banyak dikembangkan material lain yang mempunyai sifat yang sesuai dengan karakteristik material logam yang diinginkan. Salah satu material yang banyak dikembangkan saat ini adalah komposit Komposit adalah gabungan dari dua bahan atau lebih komponen yang berlainan dan mempunyai sifat yang berbeda. Selain itu ada juga yang menyatakan bahwa bahan komposit adalah kombinasi bahan tambah yang berbentuk serat, butiran seperti pengisi serbuk logam, serat kaca, karbon, aramid (Kevlar), keramik dan serat logam dalam bulat panjang yang berbeda-beda di dalam Matriks (Kroschwitz dkk, 1987).

Material penyusun komposit harus mempunyai proporsi jumlah yang jelas, yaitu serat sebagai penguat biasa disebut fiber serta pengikat disebut matriks katakanlah lebih besar dari 5\%. Kedua, material penyusunan memiliki sifat yang berbeda dan juga sifat dari komposit yang terbentuk berbeda dari sifat-sifat material penyusunan. Beberapa jenis serat alam yang telah dimanfaatkan sebagai penguat komposit diantaranya serat nanas, serat eceng gondok, sisal, rami, flax, e-glas, abaca, serat kelapa dan serat bambu (Bakri 2011). Menurut Maulida, 2006 serat batang pisang dan serat pandan digunakan untuk menggantikan serat sintetis dan polipropilen digunakan sebagai matriks, kekuatan serat batang pandan dengan ketebalan $1 \mathrm{~mm}$ lebih baik dibandingkan kekuatan tarik serat batang pisang dengan ketebalan yang sama, semakin tebal komposit yang dihasilkan maka semakin rendah kekuatan tariknya pada jumlah serat yang sama. Menurut, Nasmi 2011 analisa kekuatan tarik komposit thermoplastik diperkuat serat pohon pisang, pembuatan komposit dilakukan secara hand lay up, bahan yang digunakan adalah resin polyester dan variasi fraksi volume adalah 20\%, 30\% dan 35\%. Hasil pengujian menunjukan kekuatan tarik terbesar rata-rata terdapat pada fraksi volume 35\%. Menurut Tumpal, 2013, pengaruh fraksi volume serat batang pisang bermatriks recycled polypropylene (RPP) terhadap sifat mekanik dan sifat fisik, pembuatan komposit dilakukan secara 
hand lay up, bahan yang digunakan adalah recycled polypropylene dan variasi fraksi volume adalah filler $15 \%$, filler $20 \%$, filler $25 \%$, filler $30 \%$ dan filler $35 \%$.

Hasil pengujian menunjukan kekuatan sifat mekanik terbesar rata-rata terdapat pada fraksi volume $35 \%$ dimana pada kekuatan tarik tertinggi. Menurut Kuncoro, 2006 mechanical bonding komposit yang diperkuat serat alam dengan perlakuan kimia seperti perlakuan alkali terhadap sifat tarik komposit berpenguat serat rami kontinu dengan matriks polyester. Serat sabuk kelapa menunjukan kekuatan tarik yang lebih baik pada alkali 2\%. Menurut Junior, 2010 melakukan penelitian tentang sifat mekanis komposit serat kelapa dengan resin poliester. Setelah dilakukan pengujian dan foto SEM didapatkan fraksi volume serat yang optimal dari komposit serat kelapa yang dapat menahan perambatan retak. Menurut Lokantara , 2010 meneliti tentang pengaruh panjang serat dan temperatur udara terhadap kekuatan tarik komposit polyester tapis kelapa dengan variasi panjang serat tapis kelapa yaitu 5 $\mathrm{mm}, 10 \mathrm{~mm}$ dan $15 \mathrm{~mm}$ sedangkan variasi temperatur udara yaitu $-5^{\circ} \mathrm{C}, 10^{\circ} \mathrm{C}$ dan $25^{\circ} \mathrm{C}$. Komposit yang dibuat menggunakan penguat serat tapis kelapa dengan matriks berupa resin unsaturated polyester, hasil pengujian menunjukan variasi panjang serat dan temperatur udara mempengaruhi kekuatan tarik pada komposit.

Menurut Basuki (2008) meneliti tentang analisa sifat mekanik komposit epoksi dengan penguat serat pohon aren (ijuk) model lamina berorientasi sudut acak (random). Dari hasil pengujian diperoleh nilai kekuatan tarik rata-rata pada komposisi berat serat $20 \%$ dan $30 \%$ berturut-turut sebesar $2,577 \mathrm{~kg} / \mathrm{mm}^{2}$ dan $2,251 \mathrm{~kg} / \mathrm{mm}^{2}$, menurun dibandingkan dengan komposisi $100 \%$ dengan kekuatan tarik sebesar 3,687 kg/mm2. Pada komposisi berat serat $40 \%, 50 \%$ dan $60 \%$ kekuatan tarik rata-rata cenderung meningkat dibanding $100 \%$ epoksi yaitu 5, $128 \mathrm{~kg} / \mathrm{mm}^{2}, \quad 3,921 \mathrm{~kg} / \mathrm{mm}^{2}$ dan $3,762 \mathrm{~kg} / \mathrm{mm}^{2}$. Sedangkan pada uji impact menunjukan terjadi kenaikan dan penurunan energi impact dari fraksi berat serat $20 \%-60 \%$, sehingga yang memiliki energi impact tertinggi adalah $40 \%$ yaitu $11,132 \mathrm{Joule} / \mathrm{mm}^{2}$. Penelitian yang akan dilakukan menggunakan serat dan cara penyusunan serat. Matriks yang akan digunakan berupa plastik recycled polypropylene (RPP) sedangkan serat yang digunakan adalah serat batang pisang kepok yang disusun secara tegak lurus dan sejajar arah serat. Pada penelitian ini akan dilakukan pengujian kekuatan sifat mekanik pada komposit recycled polypropylene (RPP) dengan serat batang pisang kepok. Adapun tujuan yang diharapkan adalah sebagai berikut: Untuk mengetahui pengaruh fraksi volume serat batang pisang bermatriks recycled polypropylene (RPP) terhadap kekuatan tarik, kekuatan bending, kekuatan impact serta SEM.

\section{METODOLOGI PENELITIAN}

Adapun langkah-langkah ekstraksi untuk mendapatkan serat sebagai berikut: Pengambilan pelepah batang pisang kepok, kemudian dipotong dengan panjang $40 \mathrm{~cm}$ lalu dijemur selama 3 hari yang bertujuan untuk mengurangi kadar air, lalu memanaskan air sampai $20{ }^{\circ} \mathrm{C}$ dengan perbandingan 32,5 gr $\mathrm{NaOH}$ dengan 1 liter air, kemudian dimasukan pelepah pisang kepok dan direbus selama 1 jam kedalam larutan $\mathrm{NaOH}$ yang telah mendidih. Setelah selesai proses ekstraksi serat pelepah dioven pada temperatur $80^{\circ} \mathrm{C}$ selama 10 jam untuk mengeringkan serat, lalu dilakukan penyisiran untuk menghindari serat yang menggumpal. Seperti Gambar 1 dan Gambar 2.

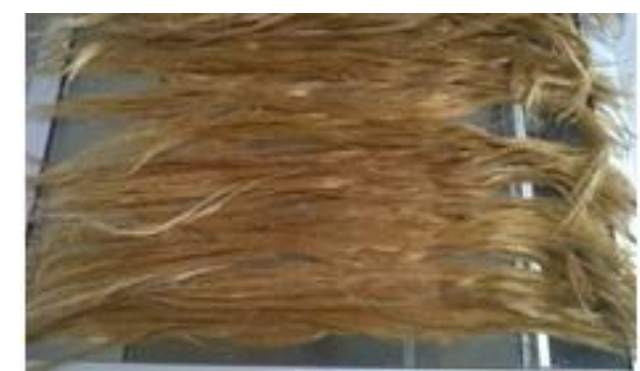

Gambar 1. Serat Setelah diekstraksi, Juni 2014

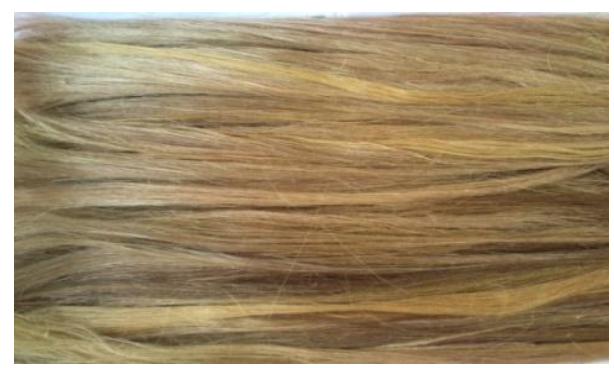

Gambar 2. Serat Setelah Disisir, Juni 2014

Adapun proses yang dilakukan untuk mendapatkan RPP yaitu dengan langkah langkan sebagai berikut: mengumpulkan sisa gelas plastik aquades bekas dan cuci bersih lalu dicacah dan dicuci kembali di dalam bak pencucian dan dijemur. Setelah itu dimasukan kemesin pencetak bijih plastik untuk mendapatkan butiran RPP. Seperti pada Gambar 3.

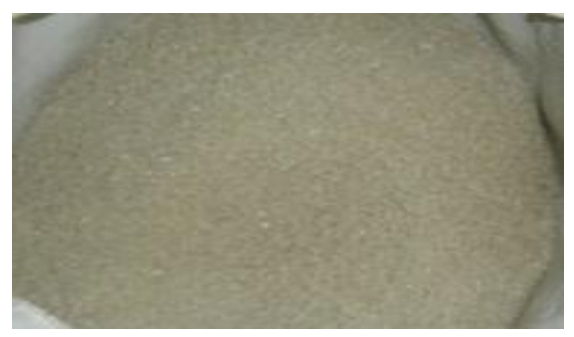

Gambar 3. Recycled Polypropylene (RPP), Juni 2014 
Pembuatan komposit dengan proses hot press dengan menyiapkan cetakan komposit. Timbang serat sesuai dengan fraksi yang dilakukan yang berfungsi sebagai faiber serta rpp berfungsi sebagai matriks, masukkan serat kedalam cetakan komposit sekaligus disusun rata. Memasukkan matriks kedalam cetakan komposit serta meratakan matriks dibawah dan diatas serat. Cetakan ditutup dan siap dimasukkan kemesin hot press dengan temperatur $167{ }^{\circ} \mathrm{C}$ dan diberikan beban sebesar 2 bar dengan penekanan yang bertahap.

\section{HASIL DAN PEMBAHASAN}

Hasil Pengujian Uji Tarik Komposit

Tabel 1. Hasil Uji Tarik Komposit

\begin{tabular}{|c|c|c|c|c|}
\hline \multicolumn{5}{|c|}{ Tabel Hasil Uji Tarik } \\
\hline \multirow{3}{*}{$\begin{array}{l}\text { Fraksi } \\
\text { Volume }\end{array}$} & \multicolumn{4}{|l|}{ Pengujian } \\
\hline & Tegangan & Regangan & Beban & Modulus \\
\hline & $\begin{array}{l}\text { Tarik } \\
\left(\mathrm{N} / \mathrm{mm}^{2}\right)\end{array}$ & $\begin{array}{l}\text { Tarik } \\
(\%)\end{array}$ & $\begin{array}{l}\text { Maksimum } \\
(\mathrm{N})\end{array}$ & $\begin{array}{l}\text { Elastisitas } \\
\left(\mathrm{N} / \mathrm{mm}^{2}\right)\end{array}$ \\
\hline $8 \%$ & 36.9339 & 3.64171 & 924.718 & 2288.72 \\
\hline $12 \%$ & 32.7952 & 3.64470 & 894.335 & 1994.43 \\
\hline $38 \%$ & 59.3200 & 3.66416 & 1737.89 & 2947.04 \\
\hline $42 \%$ & 42.0821 & 3.41515 & 1360.29 & 2691.28 \\
\hline
\end{tabular}

Setelah dilakukan pengujian tarik komposit bermatriks RPP berpenguat serat batang pisang kepok tegangan tarik, rengangan tarik, beban maksimum dan modulus elastisitas cenderung mengalami peningkatan pada fraksi volume $38 \%$.

Kurva regangan fraksi volume mengalami peningkatan dan penurunan pada. Adapun regangan yang tertinggi berada pada fraksi volume Filler $38 \%$ dengan rata-rata $3,66416 \%$. Sementara mengalami penurunan pada fraksi volume Filler $42 \%$, dan regangan yang terendah pada fraksi volume Filler $8 \%$ dengan ratarata $3.64171 \%$.

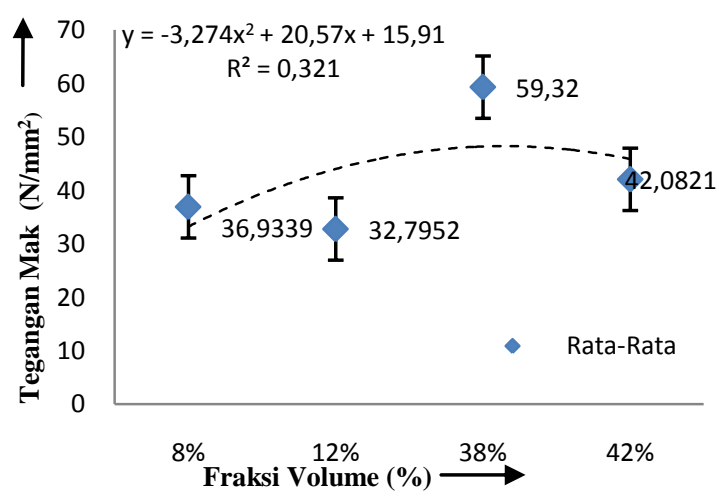

Gambar 4. Kurva Tegangan Tarik

Kurva tegangan tarik fraksi volume cenderung mengalami peningkatan dan penurunan, adapun tegangan tarik tertinggi berada pada fv $38 \%$ filler dengan rata-rata $59.3200 \mathrm{~N} / \mathrm{mm}^{2}$ dan rata-rata terendah terdapat pada fv $12 \%$ filler yaitu $32.7952 \mathrm{~N} / \mathrm{mm}^{2}$.

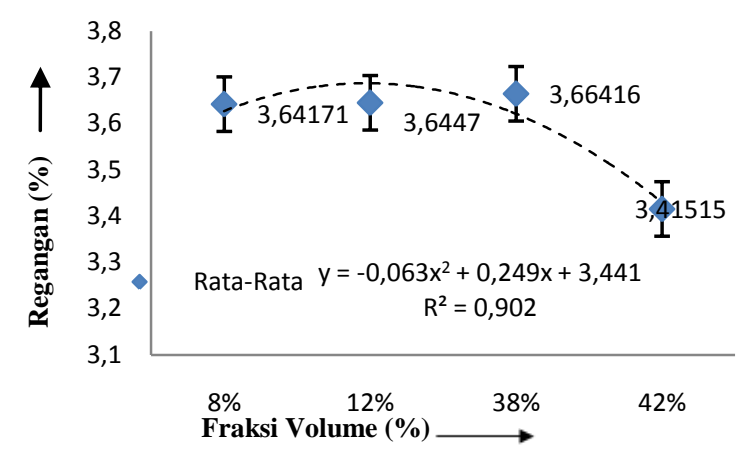

Gambar 5. Kurva Regangan Tarik

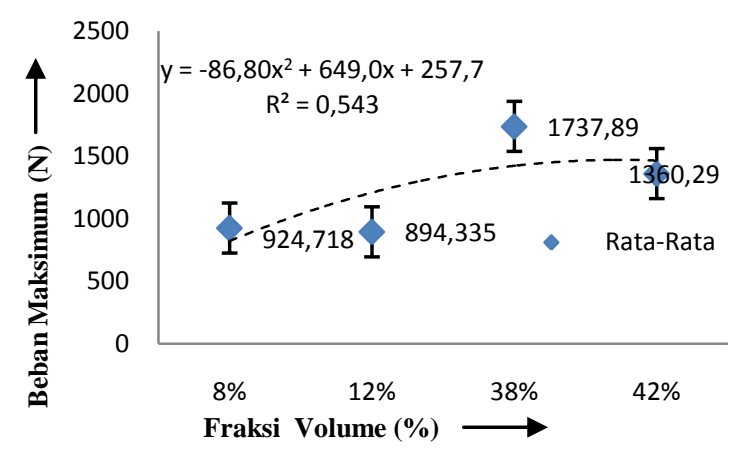

Gambar 6. Kurva Beban Maksimum

Beban maksimum fraksi volume cenderung mengalami penurunan. Adapun beban maksimum yang tertinggi berada pada fraksi volume Filler 38\% dengan rata-rata $1737.89 \mathrm{~N}$, dan mengalami sedikit penurunan pada fraksi volume Filler $42 \%$ dengan rata-rata 1360.29 N. Tetapi pada fraksi volume Filler $8 \%$ ke $12 \%$ mengalami penurunan, dimana pada fraksi volume $12 \%$ terdapat beban maksimum terendah dengan rata-rata $894.335 \mathrm{~N}$.

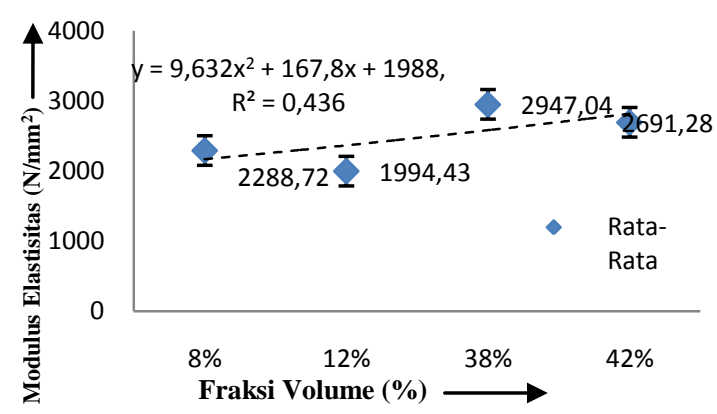

Gambar 7. Modulus Elatisitas

Kurva modulus elastisitas mengalami penurunan dan peningkatan dengan modulus elastisitas rata-rata yang tertinggi berada pada fraksi volume Filler 38\% yaitu 2947,04 N/mm ${ }^{2}$ kemudian mengalami sedikit 
penurunan pada fraksi volume Filler $42 \%$ dengan ratarata $2691,28 \mathrm{~N} / \mathrm{mm}^{2}$, yang terendah terdapat pada fraksi volume Filler $12 \%$ yaitu 1994,43 N/mm².

\section{Pembahasan}

Setelah dilakukan penambahan serat pada komposit terjadi penurunan dan peningkatan tegangan tarik pada seluruh fraksi volume. Penurunan ini terjadi karena daya ikat antara Matriks dengan serat kurang merekat dengan baik. ini disebabkan karena penyusunan serat sebagai Filler tidak merata sehingga terjadi penurunan kekuatan material komposit. Kemudian mengalami peningkatan pada fraksi volume Filler $38 \%$ dengan rata-rata $59.3200 \mathrm{~N} / \mathrm{mm}^{2}$ ini dikarenakan daya ikat antara Matriks dengan serat pelepah batang pisang sebagai Filler menjadi cukup baik, dan berfungsi sebagai penguat dengan adanya penambahan serat pelepah batang pisang kepok.

\section{Hasil Pengujian Bending Komposit}

Tabel 2. Hasil Uji Bending Komposit

\begin{tabular}{|c|c|c|c|c|}
\hline \multicolumn{5}{|c|}{ Tabel Hasil Uji Bending } \\
\hline \multirow{4}{*}{$\begin{array}{l}\text { Fraksi } \\
\text { Volume }\end{array}$} & \multicolumn{4}{|l|}{ Pengujian } \\
\hline & Tegangan & Modulus & Beban & Perpanjan \\
\hline & Lentur & Elastisita & Maksim & $\operatorname{gan}(\mathrm{mm})$ \\
\hline & $\left(\mathrm{N} / \mathrm{m}^{2}\right)$ & $\begin{array}{l}\mathrm{s} \\
\left(\mathrm{N} / \mathrm{mm}^{2}\right)\end{array}$ & $\operatorname{um}(\mathrm{N})$ & \\
\hline $8 \%$ & 46.6234 & 1659.64 & 86.6795 & 11.2728 \\
\hline $12 \%$ & 50.9861 & 1788.48 & 108.870 & 10.0713 \\
\hline $38 \%$ & 86.3001 & 5088.09 & 150.016 & 4.92771 \\
\hline $42 \%$ & 45.9044 & 1359.53 & 93.7130 & 8.67505 \\
\hline
\end{tabular}

Setelah dilakukan pengujian bending komposit bermatriks RPP berpenguat serat batang pisang kepok tegangan lentur, perpanjangan, beban maksimum dan modulus elastisitas cenderung mengalami peningkatan dan penurunan.

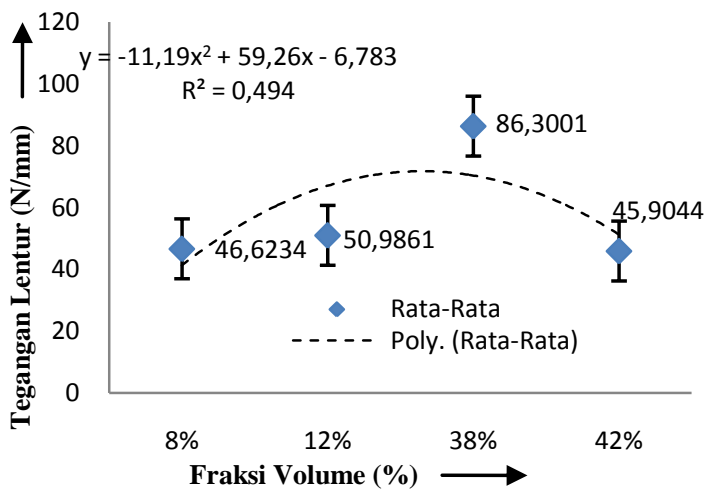

Gambar 8. Tegangan Lentur

Adapun tegangan lentur yang tertinggi berada pada fraksi volume Filler 38\% dengan rata-rata 86.3001 $\mathrm{N} / \mathrm{mm}^{2}$, dan yang terendah pada fraksi volume Filler
$42 \%$ dengan rata-rata sebesar $45.9044 \mathrm{~N} / \mathrm{mm}^{2}$. Ini disebabkan karena daya ikat serat pelepah batang pisang dengan Matriks kurang baik dan pencampuran ntara serat dan Matriks tidak merata serta terdapat rongga udara .

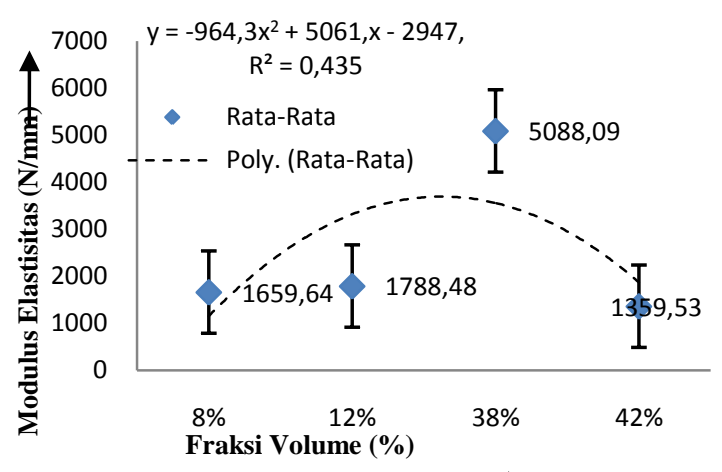

Gambar 9. Modulus Elastisitas

Modulus elastisitas fraksi volume serat pelepah batang pisang mengalami peningkatan dan penurunan. Adapun rata-rata modulus elastisitas yang tertinggi berada pada fraksi volume Filler 38\% yaitu 5088.09 $\mathrm{N} / \mathrm{mm}^{2}$, namun mengalami penurunan pada fraksi volume Filler $42 \%$ yaitu sebesar 1359,53 N/mm², disebabkan karena daya ikat serat pelepah batang pisang dengan Matriks kurang cukup baik dan kadar lignin yang masih ada sehingga dapat mempengaruhi terhadap modulus elastisitas.

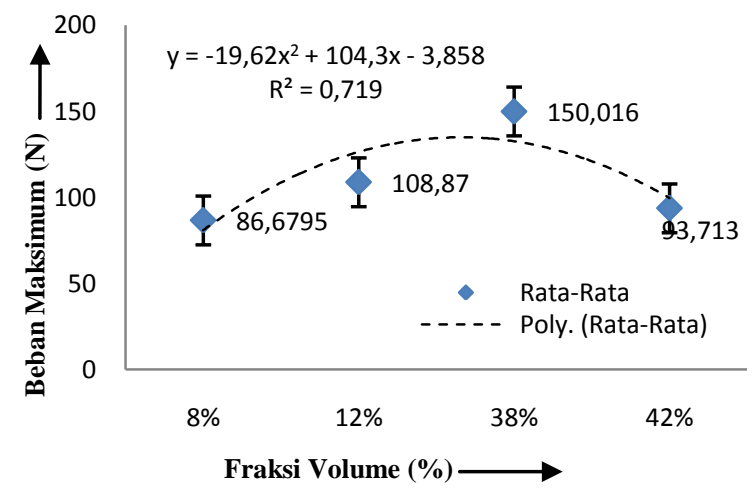

Gambar 10. Beban Maksimum

Beban maksimum fraksi volume serat pelepah batang pisang yang tertinggi pada fraksi volume Filler $38 \%$ dengan rata-rata $150.016 \mathrm{~N}$, dan yang terendah pada fraksi volume Filler $8 \%$ dengan rata-rata 86.6795 N. Hal ini disebabkan karena daya ikat serat pelepah batang pisang dengan Matriks kurang cukup baik serta penyebaran antara serat dan Matriks tidak merata. 


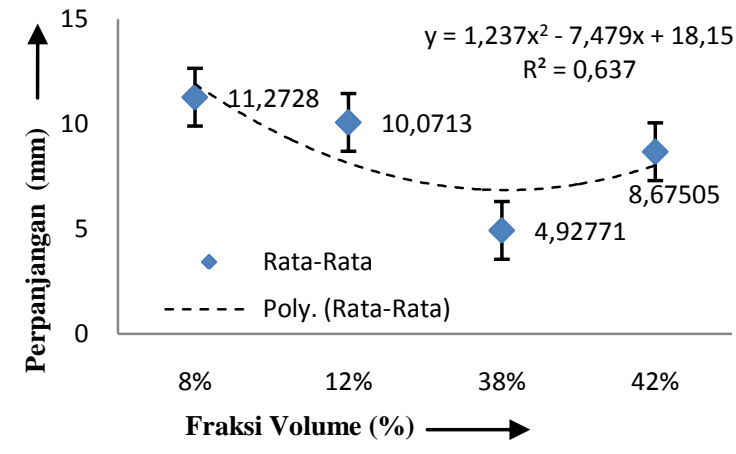

Gambar 11. Perpanjangan

Penambahan perpanjangan uji bending cenderung mengalami peningkatan dengan rata-rata yang paling tinggi terdapat pada fraksi volume Filler 38\% yaitu $4.92771 \mathrm{~mm}$. Fariasi perepanjangan karena terjadi penyebaran antara Matriks dan Filler pada saat pencetakan komposit tidak merata sehingga daya ikat Filler dan Matriks kurang baik. Bila dilihat dari keseluruhan fraksi volume, terlihat jelas perbedaan perpanjangan pada fraksi volume yang mengalami perubahan yang siknifikan.

\section{Pembahasan}

Pada penelitian ini, pembahasan utamannya diarahkan untuk mengetahui sifat mekanis dan sifat fisik dari material komposit dengan fraksi volume antara serat pelepah batang pisang kepok sebagai penguat (Filler) dengan Recycled Polypropylene (RPP) sebagai pengikat (Matriks). Mengacu pada hasil yang diperoleh setelah dilakukan penambahan serat pelepah batang pisang pada komposit mengalami peningkatan dan penurunan kekuatan yang dihasilkan dari material komposit. Kurva tegangan bending fraksi volume adalah gambaran antara nilai kekuatan dengan tingkat lendutan yang terjadi pada proses uji bending. Pada matriks Recycled Polypropylene (RPP) terlihat bahwa pada saat material menerima beban kekuatannya tidak terus meningkat hingga material putus yang terdapat pada fraksi volume Filler $38 \%$, terjadi karena adanya komposisi serat batang pisang kepok yang sebanding serta kandungan lignin berkurang dan susunan serat teratur.

\section{Hasil Pengujian Impact}

Tabel 3. Tabel Hasil Uji Impact Komposit

\begin{tabular}{|c|c|c|c|}
\hline \multicolumn{4}{|c|}{ Tabel Hasil Uji Impact } \\
\hline \multirow{2}{*}{$\begin{array}{l}\text { Fraksi } \\
\text { Volume }\end{array}$} & \multicolumn{3}{|l|}{ Pengujian } \\
\hline & $\begin{array}{l}\text { Energy Impact } \\
(\mathrm{J})\end{array}$ & $\begin{array}{l}\text { Energy } \\
\text { Koreksi (J) }\end{array}$ & $\begin{array}{l}\text { Kekuatan } \\
\text { Impact }\left(\mathrm{kJ} / \mathrm{m}^{2}\right)\end{array}$ \\
\hline $8 \%$ & 1,138 & 1,172 & 22,071 \\
\hline $12 \%$ & 1,638 & 1.625 & 24,741 \\
\hline $38 \%$ & 1,505 & 1,494 & 24,774 \\
\hline $42 \%$ & 1,821 & 1,953 & 25,252 \\
\hline
\end{tabular}

Setelah dilakukan pengujian impact komposit bermatriks RPP berpenguat serat batang pisang kepok energy impact, energy koreksi, kekuatan impact cenderung mengalami peningkatan.

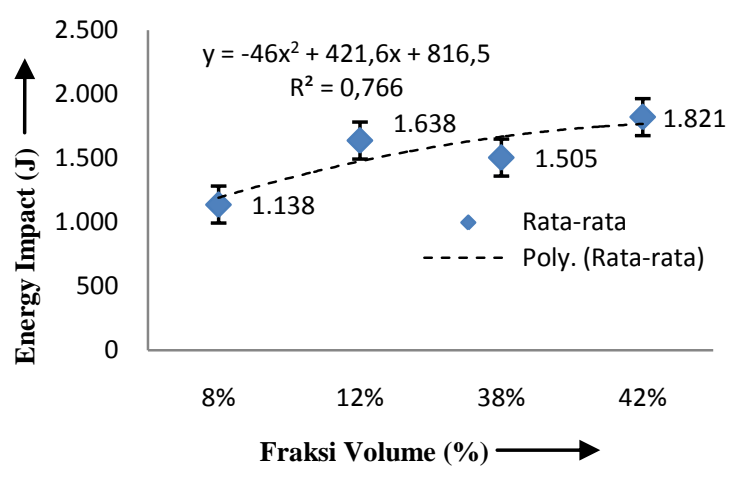

Gambar 12. Perpanjangan

Data energi Impact yang diambil merupakan kekuatan Impact dari empat fraksi volume kekuatan energi impact rata-rata yang tertinggi terdapat pada fraksi volume Filler $42 \%$ yaitu sebesar 1,821 Joule dan nilai rata-rata terendah terdapat pada fraksi volume Filler $8 \%$ yaitu 1,138 Joule. Peningkatan energy Impact seiring dengan penambahan serat atau fraksi volume semakin meningkat, serta disebabkan adanya peningkatan daya ikat antara Martiks dengan Filler yang sangat baik. Pada saat diberikan beban dari luar yang pertama mengalami putus adalah Matriks, kemudian diikuti serat itu sendiri dan serat tersebut tidak mengalami putus sekaligus tetapi masih ada sebagian serat yang masih utuh sehingga energi Impact komposit mengalami peningkatan yang signifikan.

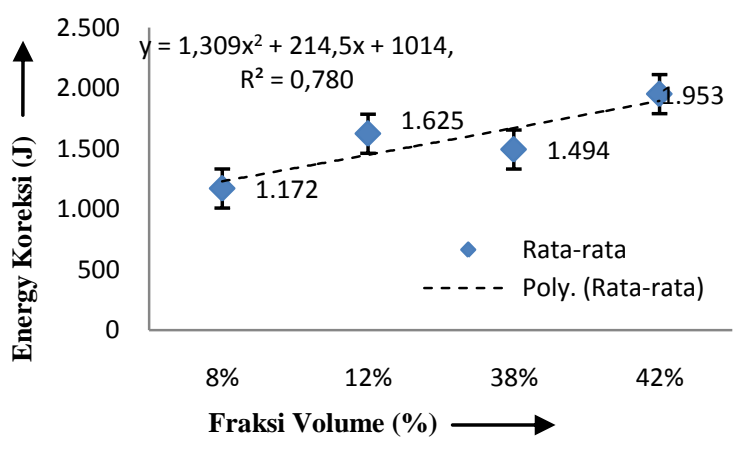

Gambar 13. Energy Koreksi

Energi koreksi yang diambil merupakan hasil dari empat volume fraksi dengan nilai rata-rata yang tertinggi terdapat pada fraksi volume Filler $42 \%$ sebesar 1,953 Joule dan nilai rata-rata terendah terdapat pada 


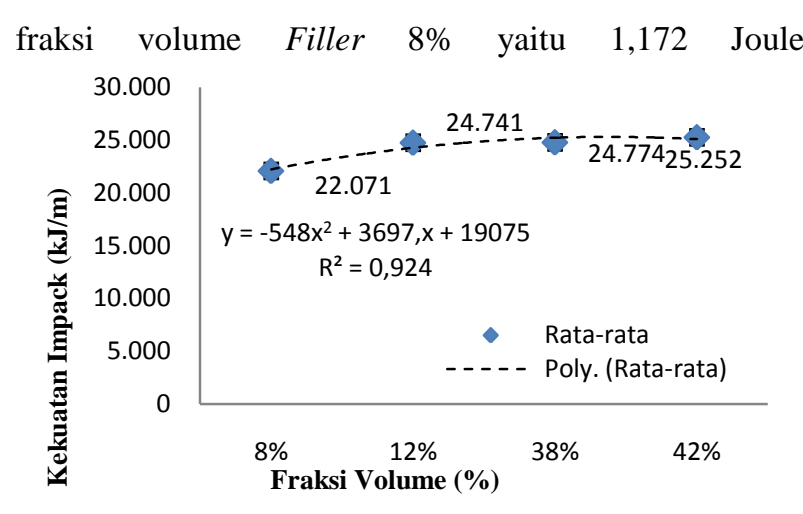

Gambar 14. Kekuatan Impact

Sementara bila ditinjau dari kekuatan Impact, kekuatan nilai rata-rata tertinggi terdapat pada fraksi volume Filler $42 \%$ sebesar $25,252 \mathrm{~kJ} / \mathrm{m}^{2}$ dan nilai ratarata terendah terdapat pada fraksi volume Filler $8 \%$ yaitu $22,071 \mathrm{~kJ} / \mathrm{m}^{2}$.

\section{Pengamatan SEM Komposit.}

Analisa Scanning Electron Microscope (SEM) dilakukan setelah pengujian kekuatan tarik (daerah patahan tarik) untuk mengetahui struktur ikatan antara serat sebagai penguat (Filler) dengan RPP sebagai pengikat (Matriks). Spesimen yang mengalami patahan dibentuk kembali menjadi spesimen pengamatan SEM foto SEM dilakukan pada komposit yang memiliki nilai tegangan tarik tertinggi pada fraksi volume Filler 38\%, dan yang terendah pada fraksi volume Filler $12 \%$.

\section{a. SEM Dengan Fraksi Volume Filler $38 \%$}
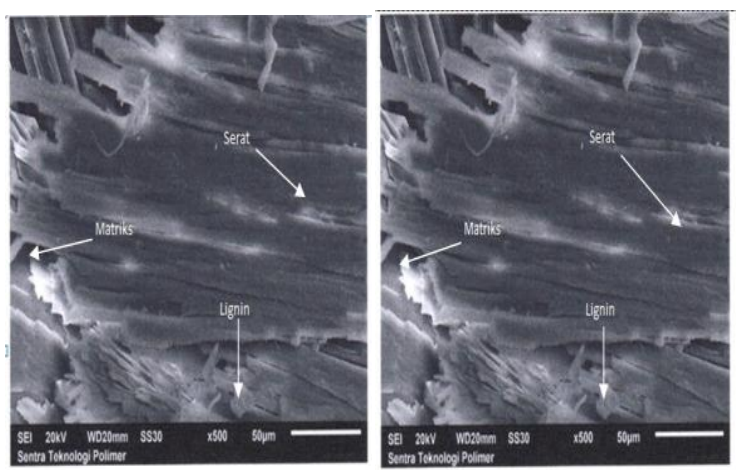

Gambar 15. Pengamatan SEM Komposit Tegangan Tarik Tertinggi

Dari Gambar 15, fraksi volume dengan campuran Filler 38\% Matriks $62 \%$ terlihat seratnya merekat dengan baik, dapat dilihat setelah kerusakan permukaan komposit setelah uji tarik, masih sedikit terlihat adanya serat yang tercabut dan menimbulkan pori, menunjukkan kekuatan ikatan matriks semakin bagus. b. SEM Dengan Fraksi Volume Filler $12 \%$
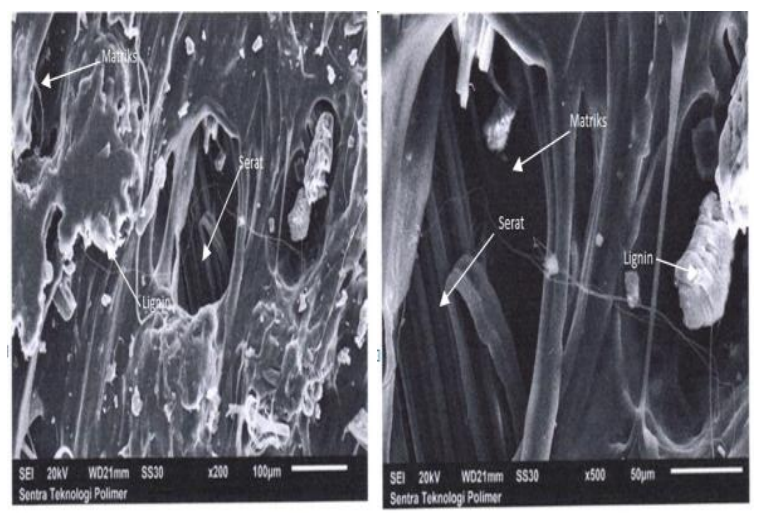

Gambar 16. Pengamatan SEM Komposit

TeganganTarik Terendah

Dari Gambar 16. perbandingan Filler 12\%, Matriks $88 \%$ menunjukkan kekuatan ikatan Matriks semakin menurun dan terlihat serat yang tercabut, serta terdapat banyak pori, hal ini dikarnakan tidak terjadi ikatan yang baik antara Filler dan Matriks pada material komposit.

\section{KESIMPULAN}

a) Dari hasil uji tarik semakin besar fraksi volume tidak mempengaruhi ke sifat mekanik tegangan tarikn maksimum, namun hanya pada fraksi volume Filler $38 \%$ : Matriks $62 \%$ yang dapat mencapai nilai ratarata tertinggi yaitu $59.3200 \mathrm{~N} / \mathrm{mm}^{2}$, dan yang terendah pada fraksi volume Filler 12\%: Matriks $88 \%$ yaitu $32.7952 \mathrm{~N} / \mathrm{mm}^{2}$.

b) Dari hasil uji bending semakin besar fraksi volume tidak mempengaruhi terhadap sifat mekanik tegangan lentur bending, namun hanya pada fraksi volume Filler 38\% : Matriks $62 \%$ yang mencapai nilai ratarata tertinggi yaitu $86.3001 \mathrm{~N} / \mathrm{mm}^{2}$, dan yang terendah pada fraksi volume Filler $42 \%$ : Matriks $58 \%$ yaitu $45.9044 \mathrm{~N} / \mathrm{mm}^{2}$.

c) Dari hasil uji pukul takik (Impact) semakin besar fraksi volume maka ketangguhan material komposit akan semakin besar (Ulet, namun tidak bisa dilakukan perbandingan fraksi volume lebih dari Filler 50\% : Matriks 50\%. Karena daya ikat antara serat dan Matriks sudah tidak dapat mengikat dengan baik.

d) Ditinjau dari hasil SEM, hanya pada fraksi volume 38\% Matriks dan seratnya merekat dengan baik, terlihat terjadi kerusakan baik pada permukaan RPP (Matriks) maupun pada penguatnya (Filler), ini menunjukan kekuatan ikatan antara matriks dan penguatnya tidak terikat dengan baik.

\section{DAFTAR PUSTAKA}

[1] Annual Book of ASTM Standards, D790 ,"Standard Test Method For Flexural Properties Of Unreinforced And Reinforced Plastics And 
Electrical Insulating Material", ASTM Standards and Literature References for Composite Materials, 2nd ed., 34-37, American Society for Testing and Material, Philadelphia, PA (1997).

[2] Bakri, 2011, "Tinjauan Aplikasi Serat Sabut Kelapa sebagai Penguat Material Komposit, Jurnal Mekanikal", Vol. 2, No. 1, ISSN 2086-3403, 10-15

[3] Diharjo, Kuncoro. 2006, "Pengaruh Perlakuan Alkali Terhadap Sifat Tarik Bahan Komposit Serat Rami-Polyester". Jurnal Mekanikal Vol. 8, No. 1, April 2006: 8-13.

[4] H.P.G. Santafé Júnior, 2010, Mechanical Properties of Tensile Tested Coir Fiber Reinforced Polyester Composites. Revista Material.

[5] Kroschwitz J L., Grestle, 1987, Encyclopedie of Polymer Science anf Engineering, $2^{\text {nd }}$ ed. John Wiley and Sons Inc.,New York.

[6] Lokantara I Putu, 2010. Pengaruh Panjang Serat pada Temperatur Uji yang BerbedaTerhadap Kekuatan Tarik Komposit Polyester Serat Tapis Kelapa. Jurnal Ilmiah Teknik Mesin Vol. 4 No.2. Oktober 2010 (166-172)

[7] Maulida. 2006, "Perbandingan Kekuatan Tarik Komposit Polipropilena Dengan Pengisi Serat Pandan dan Serat Batang Pisang”. Jurnal Teknologi Proses 5(2) Juli 2006 : 148-150, ISSN 1412-7814: 151-153.
[8] Nasmi Herlina Sari. 2011. "Ketahanan Bending Komposit Hybrid Serat Batang Kelapa/Serat Gelas Dengan Matriks Urea Formaldehyde”. Jurnal Ilmiah Teknik Mesin Cakra M. Vol. 5: 91-97.

[9] Tumpal Ojahan R 2013. Pengaruh Fraksi Volume Serat Batang Pisang Bermatriks recycled polypropylene (RPP) Terhadap Sifat Mekanik dan Sifat Fisik. BKSTM, 2013

[10] Widodo Basuki, 2008. Analisa Sifat Mekanik Kompsit Epoksi Dengan Penguat Serat Pohon Aren (Ijuk) Model Lamina Berorientasi Sudut Acak (Random). Jurnal Teknologi Technoscientia. 